ARS Irene V. Small*

\title{
Pigment pur e o Corpo da côr: prática pós-pictórica e transmodernidade.
}

\section{Pigment pur and the Corpo da côr: post-painterly practice and} transmodernity.

palavras-chave: Hélio Oiticica; modernismo; monocromo; readymade

keywords:

Hélio Oiticica; modernism; monochrome; readymade

* Princeton University.
Este artigo analisa uma incidência quase contemporânea da prática pós-pintura - o uso de pigmento bruto -, utilizada pelo artista neo-avant-garde francês Yves Klen e pelo artista brasileiro Hélio Oiticica. O uso de pigmento bruto por ambos artistas foi condicionado por uma relação autoconsciente com a história da arte modernista e do monocromo, como limite e origem da pintura. Apesar da confluência de tais orientações, os Pigments purs (pigmentos puros) de Klein e o Corpo da côr de Oiticica resultaram em orientações radicalmente divergentes, direcionadas à commodity produzida industrialmente e, portanto, ao readymade. Ao explorar as inconsistências características da commodity no Brasil desenvolvimentista, Oiticica orquestrou uma transferência do fazer do artista para o espectador, dando início a uma nova dimensão participativa no âmbito das cores modernistas.

This article analyzes a near-contemporaneous incidence of post-painterly practice - the use of raw pigment—utilized by the French neo-avant-garde artist Yves Klein and the Brazilian artist Hélio Oiticica. The use of raw pigment by both artists was conditioned by a self-conscious relationship to the history of modernist art and the monochrome as a limit and origin of painting. Despite the confluence of such orientations, Klein's Pigments purs (pure pigments) and Oiticica's Corpo da côr (body of color) resulted in radically divergent orientations towards the industrially-produced commodity and hence the readymade. By exploiting inconsistencies characteristic of the commodity in developmentalist Brazil, Oiticica orchestrated a transfer of making from artist to viewer, initiating a newly participatory dimension within modernist color. 
Nos últimos anos, pesquisadores invocaram modernismos "alternativos", "síncronos" e "múltiplos" para complicar a noção de modernidade como um fenômeno ocidental que se espalha para a chamada periferia, e que apaga, em sua escalada, expressões locais de diferença ${ }^{1}$. Tais recortes têm catalisado a recuperação de práticas estéticas anteriormente negligenciadas à luz de matrizes hegemônicas de influência, inovação e crítica artística. Não obstante, em razão de sua insistência na importância global de certas expressões, como o readymade, o monocromo e a incisão, o modernismo, enquanto discurso artístico-histórico, permanece distinto de metodologias regionais. Da mesma maneira, apesar da retórica da autonomia muitas vezes atribuída a práticas modernistas descentradas, diversos protagonistas originais alegaram afinidade direta com narrativas totalizantes do modernismo ocidental, como a vanguarda. Foi este o caso, por exemplo, do neoconcretismo brasileiro na década de 1950, explicitamente entendido por Ferreira Gullar, seu principal teórico, como uma continuação — de fato, a culminação — da arte europeia avançada oriunda da ruptura cubista da década de $1910^{2}$. Apesar disso, no neoconcretismo, assim como em muitos outros movimentos, essas filiações estavam longe de ser simples e constituem uma política de desestabilização em si e de si mesmas ${ }^{3}$. Postular um modernismo "paralelo" a tais manifestações artísticas anularia, assim, seu grau de intervenção na modernidade em geral.

Ao invés de aderir ao discurso eurocêntrico do fluxo centro-periferia, ou a uma narrativa romanceada de autoctonia indígena, procuro, neste artigo, situar e analisar uma incidência específica e quase contemporânea da prática pós-pictórica - o uso de pigmento bruto - pelo artista francês Yves Klein (protagonista central da neovanguarda europeia) e pelo artista brasileiro Hélio Oiticica (membro chave do Neoconcretismo). O uso de pigmento bruto por Oiticica e por Klein foi condicionado por uma relação autoconsciente com a história da arte modernista, especificamente com o tropo do monocromo enquanto limite e origem da pintura. As primeiras obras de Oiticica demonstram um compromisso claro com o suprematismo de Kazimir Malevich, ensaiando os tropos estilísticos do artista russo em pinturas a guache de 1954-1955 (produzidas no âmbito do Grupo Frente, de artistas atuantes no Rio de Janeiro) e partindo das pinturas em branco sobre branco daquele artista em sua Série Branca de 1958-19594.

$\mathrm{Na}$ versão de Oiticica destas obras monocromáticas, diversos níveis de saturação de pigmento criam diferenciação tonal dentre os brancos, deslocando a ênfase, de uma abstração purificada para o
256

Irene V. Small

Pigment pur e o Corpo da côr: prática pós-pictórica e transmodernidade.

1. A literatura e debates sobre modernidades múltiplas e alternativas é extensa. Cf. a edição especial "Multiple Modernities", Daedalus, Cambridge, MA, v. 129, n. 1, inverno 2000; MITCHELL, Timothy (ed.). Questions of modernity. v. 11. Minneapolis: University of Minnesota Press, 2000. (Série Contradictions of modernity); GAONKAR, Dilip (ed.). Alternative modernities. Durham: Duke University Press, 2001. (Série Millennial quartet book); CHAKRABARTY, Dipesh. Provincializing Europe: postcolonial thought and historical difference. Princeton, NJ: Princeton University Press, 2008. (Série Princeton studies in culture/power/historyl. Com relação específica à arte e à história da arte, cf. MERCER, Kobena (ed.). Cosmopolitan modernisms. Cambridge, MA: MIT Press, 2005. (Série Annotating art's histories); BOURRIAUD, Nicholas.

Altermodern (catálogo da exibição). London: Tate, 2009; a edição especial "African Modernism", South Atlantic Quarterly, Durham, v. 109, n. 3, verão 2010; SMITH, Terry. What is contemporary art? Chicago: University of Chicago Press, 2009. Para contra-argumentos do alcance expansivo, até "singular", da modernidade, cf. JAMESON, Fredric. A singular modernity: essay on the ontology of the present. London: Verso, 2009; CLARK, Timothy. Farewell to an idea: episodes from a history of modernism. New Haven: Yale University Press, 1999.

2. Cf. "Manifesto Neoconcreto" de Ferreira Gullar, em Jornal do Brasil, Rio de Janeiro, 
23 mar. 1959. Suplemento dominical, p. 4-5, e sua série artístico-histórica "Etapas de

Arte Contemporânea," que foi publicada no "Suplemento Dominical" do Jornal do Brasil de março de 1959 a outubro de 1960. Discuti a série de Gullar em "Exit and impasse: Ferreira Gullar and the 'New History'

of the last avant-garde", em

Third Text, London, v. 26, n. 1 , p. 91-101, jan. 2012

3. Sérgio Bruno Martins, por exemplo, argumenta que o modernismo brasileiro autoconscientemente

"sequestra" o modernismo Europeu, em MARTINS, Sérgio. Constructing an avant-garde: art in Brazil 1949-1979. Cambridge, MA: MIT Press, 2013.

Fig. 1

Hélio Oiticica, Sem título (Série

Branca), 1958-59. Cortesia do Projeto Hélio Oiticica. Ifoto César Oiticica Filho

4. Em 1960, Oiticica descreveu as pinturas de Malevich como uma "representação [chegando] no seu limite". Registro em caderno, maio de 1960 ITAÚ CULTURAL. Programa

Hélio Oiticica. São Paulo, 2002, Arquivo Hélio Oiticica/ Programa Hélio Oiticica (AHO/ PHO) 0182.59, p. 8. Sobre as pinturas brancas de Malevich, cf. seu "Non-objective art and suprematism”, em HARRISON

Charles; WOOD, Paul (eds.)

Art in theory 1900-2000: an anthology of changing ideas. Oxford: Blackwell, 2003 p. 292-293. Tanto Martins como Paula Braga discutiram a relação de Oiticica e Malevich, esta última em Hélio Oiticica: singularidade, multiplicidade. São Paulo: Perspectiva, 2013. Sobre a prática de cor de Oiticica, em termos mais meio de um par de garrafas de vidro preenchidas com líquido colorido, azul transparente em uma, amarelo opaco em outra. Klein, entretanto, enquadrou sua relação com o predecessor de vanguarda em termos de reversão agressiva. Em 1954, publicou um panfleto contendo pranchas de cor supostamente representando uma série de pinturas monocromáticas suas, mas que se referiam, simplesmente, aos próprios recortes miniaturizados em papel 5 . Quatro anos mais tarde, desenhou uma caricatura, nomeada "Posição de Malevitch em relação a mim" [Position of Malevich in relation to me], que retratava o artista russo anacronicamente pintando uma natureza-morta tomada de um dos seus trabalhos monocromos. Assim, quando os dois artistas chegaram ao uso de pigmento bruto - Klein, com uma bandeja de pigmento azul ultramarino exibida em 1957; Oiticica, com uma escultura de [frascos] de vidro encaixados, intitulada B7 Bólide Vidro 1, de 1963 - eles o fizeram com plena consciência de sua própria posição em relação às vanguardas históricas.

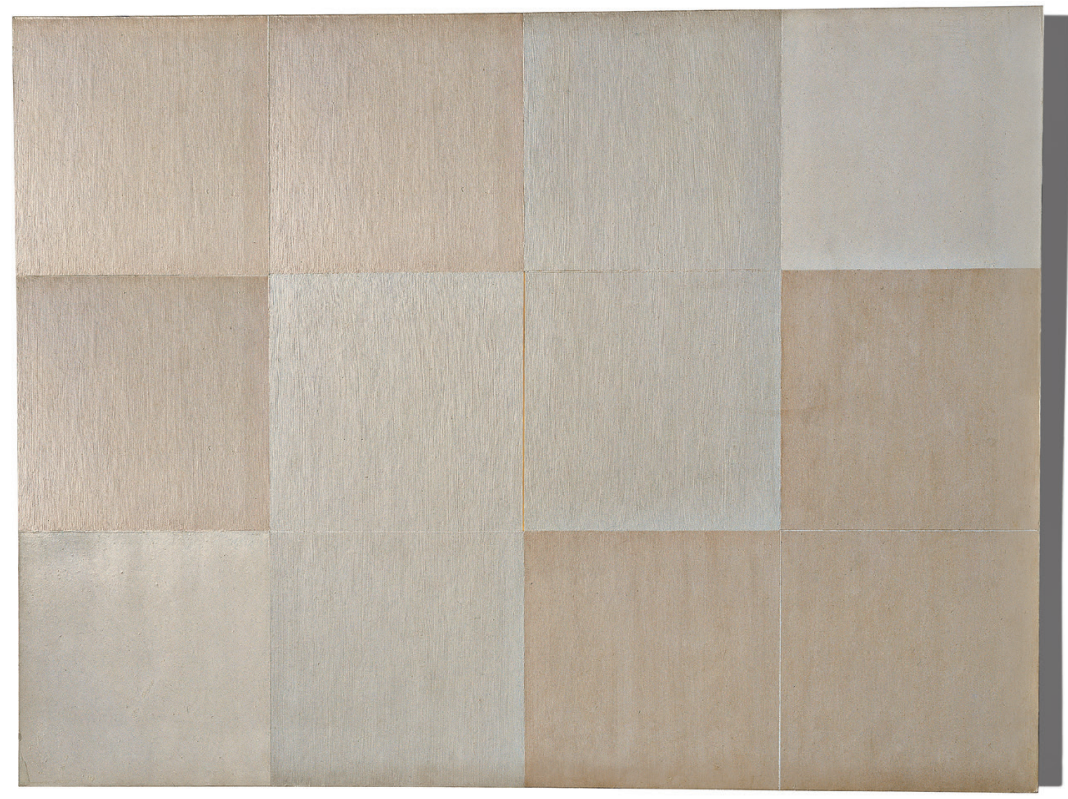

Como poderíamos descrever o significado deste uso do pigmento bruto, que é, de fato, o pigmento dissociado da tinta? Para começar, podemos talvez notar que isso equivale a uma elementarização da pintura $^{6}$. 


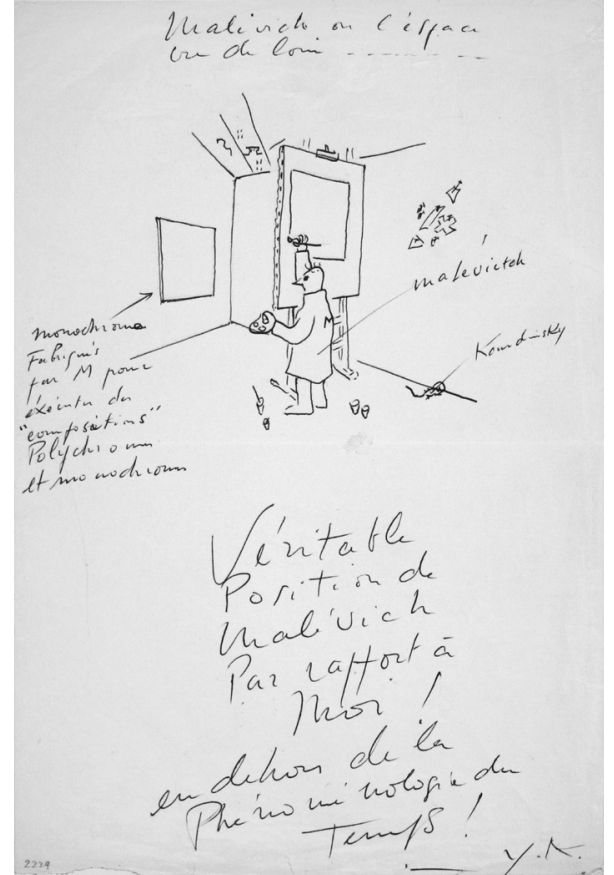

Empregando pigmento bruto em forma de pó, Oiticica e Klein propositadamente se afastaram da convenção da tinta como o principal veículo para a cor e, consequentemente, do suporte pictórico como um pré-requisito para a sua construção. O pigmento dissociado da tinta mobiliza um estado material anterior à realização física da pintura de modo a conceituar uma posição artístico-histórica que conscientemente superou a pintura como tal. Na condição de trabalhos abstratos, a bandeja de Klein e o B7 Bólide Vidro 1 de Oiticica são, decididamente, pós-representativos. Mas, como investigações espacializadas da cor, a qual, de outro modo, seria pictórica, são também pós-medium, e no caso de Oiticica, pós-plano.

Neste apelo à elementarização da pintura, as obras de Oiticica e Klein estabelecem um diálogo com o trio de pinturas de Alexander Rodchenko, Cor vermelho puro; Cor amarelo puro; e Cor azul puro, de 1921 , cada uma consistindo em um painel pintado com uma cor primária. Emergindo imediatamente do contexto da fase laboratorial do construtivismo russo e sua admonição contra o esteticismo da arte tradicional, as obras registram o abandono da pintura por Rodchenko através de um processo de dedução racional. Como ele explicou mais tarde, "Eu reduzi a pintura à sua conclusão lógica e exibi três telas: vermelho, azul e amarelo. Afirmei: Está tudo acabado. Cores básicas. Cada plano é um plano, e vai não haver nenhuma representação mais"”. Ao eliminarem
Irene V. Small

Pigment pur e o Corpo da côr: prática pós-pictórica e transmodernidade.

gerais, cf. RAMÍREZ, Mari. The embodiment of color - from the inside out. In: (ed.). Hélio Oiticica: the body of color. Houston: Museum of Fine Arts, Houston, 2007, p. 27-69. Todas as traduções são do autor, a menos que indicado o contrário.

Fig. 2

Yves Klein, Malevich or Space Viewed at a Distance. c. 1958, desenho, caneta, 31,8 x 21,4 $\mathrm{cm}$. Artists Rights Society (ARS), Nova lorque/ADAGP, Paris, 2017.

5. Sobre a importância deste panfleto para o estabelecimento da intermediação entro o pictórico e o discursivo de Klein, cf. CABAÑAS, Kaira. Let this be said and done. In: . The

myth of Nouveau Réalisme: art and the performative in postwar France. New Haven: Yale University Press, 2013, p. 31-61.

6. Sobre o princípio da elementarização le a correspondente operação de integraçãol no trabalho dos arquitetos e artistas De Stijl, cf. BOIS, Yve-Alain. The De

Stijl idea. In: Painting

as model. Cambridge, MA: MIT Press, 1990, p. 101-122.

7. Alexander Rodchenko, do manuscrito de 1939 "Working with Mayakowsky", em From painting to design: russian constructivist art of the twenties. Cologne: Galerie Gmurzyska, 1981, p. 191. Sobre a recepção das telas de Rodchenko na arte do pós-guerra, cf. BUCHLOH, Benjamin. The primary colors for the second time: a paradigm repetition of the neo-avantgarde. October, Cambridge, MA, v. 37, p. 41-52, verão 1986. 
a composição, o gosto, a habilidade e o significado simbólico, as obras

8. Uma das pinturas preto sobre preto de Rodchenko ilustra as "Etapas de Arte Contemporânea" de Ferreira Gullar na seção de NãoObjetividade e Construtivismo do "Suplemento Dominical" do Jornal do Brasil de 11 de novembro de 1959 (p. 3).

Fig. 3

Alexander Rodchenko, Cor vermelho puro, amarelo puro, azul puro, 1921. Óleo sobre tela, $62,5 \times 52,5 \mathrm{~cm}$ (cada), imagem cortesia do Arquivo A. Rodchenko e V. Stepanova,

Moscou. Propriedade de Alexander Rodchenko/RAO Moscou/VAGA, Nova lorque.

9. Oiticica desenvolveu seu conceito de "corpo de côr" ao longo da década de 1960. Em um registro feito em caderno de 5 de outubro de 1960, ele faz um uso precoce do termo quando observa que "quando (...) a cor já não é aplicada no retângulo, nem em qualquer representação desse retângulo ela tende a 'encarnar' em si; torna-se temporal, criando sua própria estrutura, e a obra torna-se então o 'corpo de cor'”. INSTITUTO ITAÚ CULTURAL. Programa Hélio Oiticica. São Paulo: Itaú Cultural, 2002, AHO/ PHO 0121.60, p. 27-29. Em seu "A transição da côr do quadro para o espaco e o sentido de construtividade", publicado em Habitat 70, de dezembro de 1962, ele identifica o "corpo de côr" de forma aproximada no Cubocor de Aluísio Carvão, de 1960, que parece implicar

a cor desagregada de um suporte tradicional. Entretanto, é apenas a partir de Bólides de Oiticica, feito com pigmento bruto, que estas preocupações são articuladas no seu próprio trabalho. prescindiam de tudo que ancorara a pintura no domínio da estética, revelando-a, em vez disso, um composto de convenções: um suporte retangular e a aplicação de cor em uma superfície plana. Além disso, por demonstrar a pintura como uma série de protocolos, a elementarização materialista de Rodchenko poderia paradoxalmente "reduzir a pintura à sua conclusão lógica" simplesmente nomeando as obras Cor vermelho puro, Cor amarelo puro, Cor azul puro. Em outras palavras, é menos importante que as cores sejam percebidas como "puras" do que como correspondentes às cores primárias, tal como são convencionalmente conhecidas.
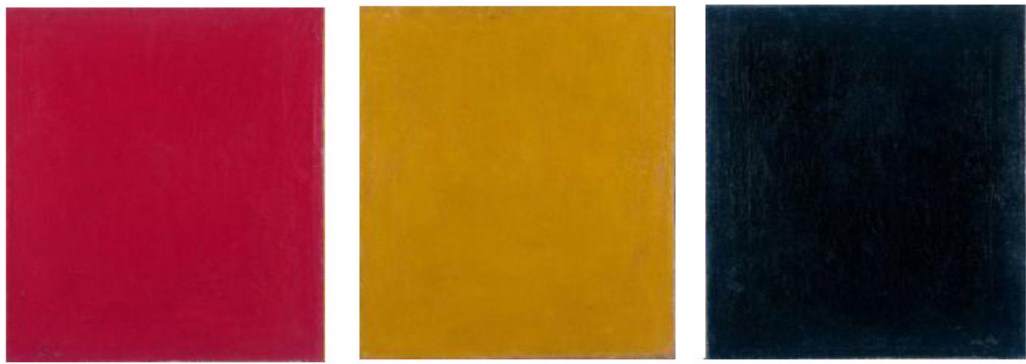

Elementarização para Oiticica, em contrapartida, envolvia uma materialidade orientada explicitamente à percepção do espectador e, fundamentalmente, sua participação - e portanto foi indiscutivelmente fenomenológica na abordagem do artista. A superfície de suas pinturas monocromáticas, variada com precisão, remodela a "conclusão lógica” à que Rodchenko chegara em 1921, por meio da fatura que o artista russo havia anteriormente explorado em suas pinturas em preto sobre preto, de $1918^{8}$. Em uma pintura vermelha triangular de sua Série Vermelha, concluída ao mesmo tempo que sua Série Branca em 1959, por exemplo, Oiticica variou a superfície de seu monocromo, alterando a direção das pinceladas ao longo de uma linha divisória central. Embora apelando a uma lógica elementarista de cores primárias, Oiticica dissolveu a noção de cor "pura" ou absoluta na contingência do encontro do espectador com a obra. Como sua trajetória subsequente indica, Oiticica não destinou esta intensidade fenomenológica à recuperação da pintura tradicional. Em vez disso, ele procurou mobilizá-la no sentido de uma noção reconfigurada de "construção", e desta maneira, alinhou suas experiências com o movimento do próprio Rodchenko em direção ao espaço. Para Oiticica, a pintura como uma categoria histórica, e, especificamente, a materialidade como um produto da elementarização da pintura, deveriam, portanto, ser exploradas não por 
conta de seus limites convencionais, mas de suas capacidades cromáticas, experienciais. Paradoxalmente, isso significava que ele estava mais interessado no pigmento puro do que na cor pura. B7 Bólide Vidro 1 simboliza esta prioridade. O trabalho consiste em um frasco de vidro de pigmento vermelho-alaranjado dentro de um frasco maior preenchido com tijolo triturado ou terra, sua tonalidade marrom-avermelhada formada a partir do óxido de ferro de pigmento natural. Ao se levantar a tampa revela-se o interstício espacial delimitado pela circunferência do frasco de vidro menor, alojado no interior, os círculos concêntricos de cor resultantes. Nas novas qualidades hápticas, materialistas da cor pigmentar desta obra, Oiticica realizou plenamente o que descreveu como um Corpo da côr. ${ }^{9}$

Como Oiticica, Klein foi atraído para as qualidades perceptivas do pigmento puro, e em 1957 expôs uma bandeja de pigmento azul ultramarino no piso da galeria, como parte de Pigment pur (pigmento puro), metade de uma exposição em dois locais simultaneamente, intitulada Yves le monochrome ${ }^{10}$. Enquanto Oiticica preferiu conceituar sua sensação de cor "construtiva" como um "corpo de côr" que interagia com o espectador através de um "campo de desenvolvimento", conforme descreveu em 1962, Klein formulou sistematicamente sua exploração cromática por meio do "imaterial" ${ }^{11}$. Para Klein, a acentuada fisicalidade do pigmento bruto era uma qualidade a ser direcionada a fenômenos decididamente desmaterializados, tais como "sensação" e "sensibilidade", e a experiência estética como um todo era concebida como um evento transcendente, não como um diálogo ou como a emergência de dois corpos que se concretizam, como era para Oiticica ${ }^{12}$.

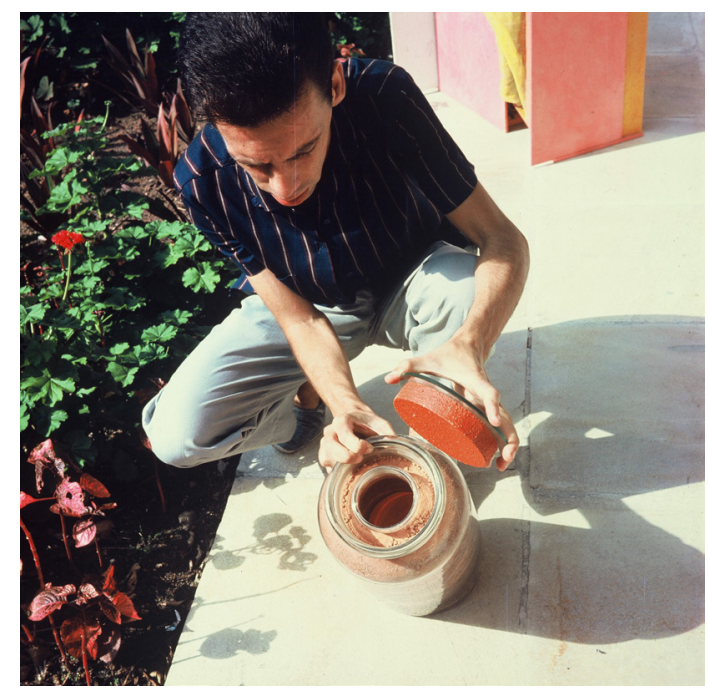

Irene V. Small

Pigment pur e o Corpo da côr: prática pós-pictórica e transmodernidade.

10. A bandeja foi exposta na Galeria Colette Allendy junto da exposição de Klein na Galeria Iris Clert, ambas em Paris.

11. OITICICA, Hélio. Registro em caderno, 22 de agosto de 1962. INSTITUTO ITAÚ CULTURAL. Programa Hélio Oiticica. São Paulo: Itaú Cultural, 2002, AHO/PHO 207.59, p. 13-14. Cf. também OTTMANN, Klaus (ed.). Overcoming the problematics of Art: the writings of Yves Klein. Putnam, CT: Spring, 2007, em particular os capítulos "The monochrome adventure" (p. 137-173) e "The evolution of art towards the immaterial: lecture at the Sorbonne, 3 June 1959" (p. 71-98).

12. KLEIN, Yves. The evolution of art towards the immaterial: lecture at the Sorbonne, 3 June 1959. In: OTTMANN, Klaus. Op. cit., p. 71-98.

Fig. 4

Hélio Oiticica, B7 Bólide Vidro 1, 1963. Cortesia do Projeto Hélio Oiticica. (foto Claudio Oiticical 
13. Idem. The monochrome adventure. In: OTTMANN,

Klaus. Op. cit., p. 154. Klein comprou seus pigmentos na loja de equipamentos parisiense Édouard Adam, um droguista de quem o artista adquiriu o pigmento azul ultramarino sintético que usou mais tarde em sua patenteada International Klein Blue (IKB). Cf. MANCUSI-UNGARO, Carol. A technical note on IKB. In: RESTANY, Pierre; MCEVILLEY,

Thomas; ROSENTHAL, Nan.

Yves Klein, 1928-1962: A

retrospective. Houston: Institute of Fine Arts - Rice University, 1982, p. 258-259.

14. Cf. em particular, "The monochrome adventure" e "Notes on certain works exhibited at Galerie Colette

Allendy", em Overcoming the problematics of Art: the writings of Yves Klein. Em seu ensaio "Assisted Levitation" (Levitação Assistida), Nan Rosenthal convincentemente argumentou que os objetos expostos na Galeria Colette Allendy funcionavam como "suplementos" para as pinturas monocromas

exibidas na Galeria Iris Clert, iluminando-as e revelando sua original, e essencial, carência. ROSENTHAL, Nan. Assisted levitation: the art of Yves Klein. In: RESTANY, Pierre; MCEVILLEY, Thomas; ROSENTHAL, Nan. Op. cit., p. 91-135.

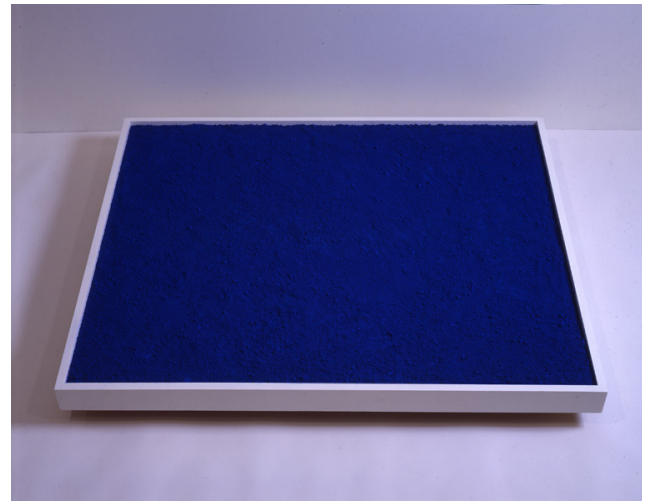

Curiosamente, Klein falava com frequência do pigmento bruto em termos vitalistas semelhantes ao discurso organicista de Oiticica. Descrevendo seus primeiros contatos com tais pigmentos ao comprar materiais em Paris em meados da década de 1950, ele observou:

Eu não tinha qualquer apreço ela tinta a óleo. As cores pareciam mortas para mim. O que me agradava, acima de tudo, eram pigmentos puros em pó, tais como muitas vezes via nos atacados de fornecedores de tinta. Eles tinham um brilho e uma vida própria, extraordinária e autônoma. Eram realmente cor por si só. A matéria viva e palpável da cor $^{13}$.

A exibição de 1957 , de pigmento bruto em um recipiente horizontal, retoma este contato original com a cor. A apresentação sem aglutinantes permitiu a Klein preservar o brilho saturado do pigmento — sua qualidade "viva" ${ }^{14}$. Embora tenha aberto uma breve dimensão participativa ao posicionar um ancinho na bandeja de pigmento, as dimensões retangulares da bandeja vincularam efetivamente seu trabalho às convenções de pintura de cavalete ${ }^{15}$. Como suas obras e textos contemporâneos indicam, Klein desejava gerar uma experiência estética através do pictórico, e assim continuou investindo em um modo especificamente contemplativo de arte. Em uma palestra, em 1959, ele observou que não seria possível deixar a bandeja horizontal de pigmento no chão, sustentada simplesmente pelo "meio fixador" de gravidade, pois "o homem naturalmente fica ereto e o olhar dele naturalmente se fixa no horizonte. A pintura deve ser apresentada ao nível dos olhos em uma posição perpendicular à terra, como uma tela" ${ }^{16}$. Vista sob este prisma, a natureza pictórica das obras de Klein não é derivada de elementos residualmente figurativos, mas de sua capacidade de agir como uma imagem, de apresentar em imagem um mundo distinto daquele do espectador. 
Para empregar os suportes pictóricos que lhe bastassem, Klein teve que encontrar um modo de imergir pigmentos brutos em um meio que permitisse sua fixação em uma superfície vertical. Para Klein, esta capacidade de unir os grãos isolados de pigmento sem perder sua qualidade autônoma vital foi a realização metafórica de uma utópica coesão social. Ele escreveu várias vezes sobre criar uma obra intitulada França, em que cada cidadão funcionaria como um grão de pigmento, juntando-se aos demais através da "sensibilidade artística"17. Além disso, imaginou esta proposição em seus "relevos planetários" de 1961, em que moldes de mapas tridimensionais do Instituto Nacional de Geografia da França eram pintados em spray com seu azul característico - significantemente, uma das obras une, em uma única faixa ultramarina, a Europa e o norte da África, a última em meio à luta argelina pela independência. Em sua palestra de 1959, Klein também sugeriu que a "sensibilidade" artística, simbolizada por este azul, agiria como uma alternativa para o fixador social existente - "o princípio monetário" — que "mumifica" os cidadãos e embota sua capacidade para uma "responsabilidade imaginativa e livre"18. A síntese de pigmento bruto e medium na pintura era nada menos do que uma alegoria nacional.

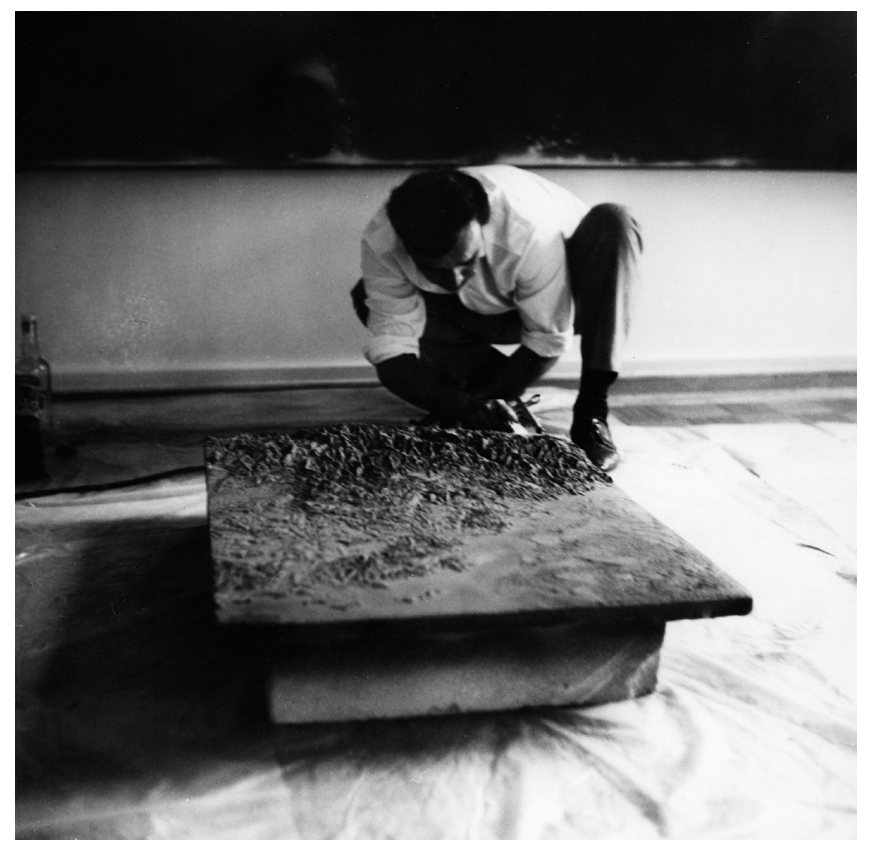

Ainda assim, Klein assumiu um papel de liderança profundamente contraditório nesta alegoria nacional. Em 1960, o artista registrou uma

\section{Irene V. Small}

Pigment pur e o Corpo da côr: prática pós-pictórica e transmodernidade.

15. HULTÉN, Pontus. Pariskonst och Jiujitsu (1957) apud ROSENTHAL, Nan. Assisted levitation: the art of Yves Klein. In: RESTANY, Pierre; MCEVILLEY, Thomas; ROSENTHAL, Nan. Op. cit., p. 112.

16. RESTANY, Pierre; MCEVILLEY, Thomas; ROSENTHAL, Nan. Op. cit, p. 93.

17. OTTMANN, Klaus Introduction. In: . Op. cit., p. xviii.

18. Idem. Op. cit., p. 93.

Fig. 6

Yves Klein making, region of Grenoble, 1961. Ifoto Gilles Raysse] 

combinação de aglutinante e pigmento ultramarino sintético, nomeando-

19. Patente $n^{\circ} 63471$, emitida pelo L'Institut nacional de la propriété industrielle. Cf. MANCUSI-UNGARO, Carol. A technical note on IKB. In: RESTANY, Pierre; MCEVILLEY, Thomas; ROSENTHAL, Nan. Op. cit.; SEMIN, Didier. Yves Klein: la propriete intellectuelle en question. In: MORINEAU, Camille. Yves Klein: corps, couleur, immatériel. Paris: Centre Georges Pompidou, 2006, p. 277-279

20. OTTMANN, Klaus. Op. cit., p. 142-143.

21. Sobre a relação de Klein com a estrutura fetichista da mercadoria, cf. DUVE, Thierry de; KRAUSS, Rosalind. Yves

Klein, or the dead dealer. October, Cambridge, MA, v. 49, p. 72-90, verão 1989.

Fig. 7

Hélio Oiticica, B11 Bólide Caixa 9 1964. Cortesia do Projeto Hélio Oiticica. (foto Claudio Oiticica) -a International Klein Blue (IKB) ${ }^{19}$. Assim, Klein patenteou não uma cor, mas a combinação química que permite que esta cor seja aglutinada enquanto matéria física e fixada visando um determinado efeito, de modo a transformar qualquer suporte em uma imagem. Se em 1959 Klein propôs a "sensibilidade artística" como uma alternativa ao princípio monetário da troca econômica, sua patente de 1960 declarava que essa "sensibilidade" deveria ser legitimada especificamente em termos de direitos autorais comerciais. Assim, em 1961, quando recriou sua bandeja de pigmento para a exposição retrospectiva em Krefeld, Alemanha, ele pôde justificadamente afirmar que suas pinturas eram apenas "as cinzas de minha arte" $^{20}$. Ele havia superado a arte em prol dos mecanismos legais da esfera da mercadoria industrializada, e sua patente produziu o fenomenal efeito da cor como um produto totalmente decomponível, ancorado nas convenções comerciais da troca econômica ${ }^{21}$.

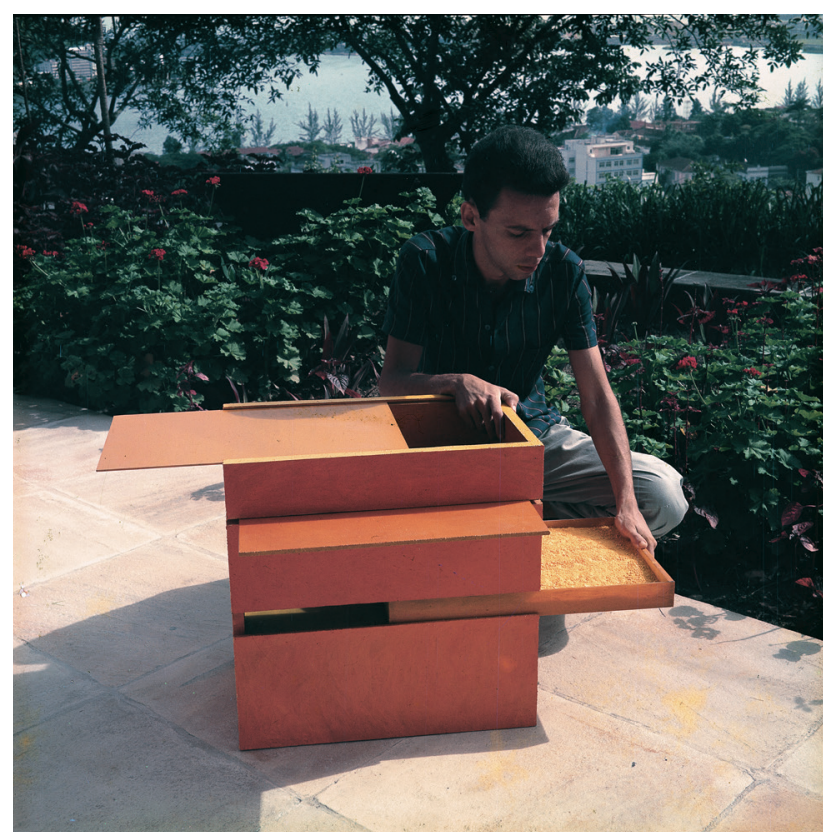

As implicações para o espectador são severas. Para Oiticica, a elementarização da pintura que culminou nos Bólides feitos com pigmento bruto, como B7 Bólide Vidro 1 e B11 Bólide Caixa 9 (1964), constituiu um processo em que um "campo de desenvolvimento" cromático era transferido gradualmente do artista para o espectador. $\mathrm{O}$ espectador agora construía o "corpo de côr" em consonância com a obra, 
e o ato de fazer expandia-se, estruturalmente, para além do autor. Em contraste, o IKB de Klein atrelava propriedade comercial à "sensibilidade artística”, restabelecendo a hierarquia tradicional do artista e espectador e ao mesmo tempo permitindo que a cor pairasse livre como uma mercadoria. O IKB transferia ao espectador não o ato de criação, mas o poder fetichista da cor comercialmente legitimada pelo autor — daí o hábito de Klein de chamar suas esculturas com esponja de retratos do "leitor", depois de ele ou ela ter viajado pelas profundezas imateriais de seu azul ultramarino. A cor era o resíduo material desta transmutação, e o espectador, uma superfície absorvente impregnada pelo ato artístico.

Como Oiticica, Klein procurou uma forma-chave (o monocromo) e uma estratégia-chave (a elementarização) da vanguarda histórica a fim de isolar a cor como uma entidade vital e experiencial, intimamente ligada à percepção do espectador da obra de arte. Para ambos os artistas, a materialidade do pigmento bruto fornecia os meios para se distanciarem de modo resoluto da renúncia de Rodchenko à cor, excedendo os limites da pintura de cavalete, mas permanecendo insistentemente cromática em sua orientação. No entanto, através de uma série de artimanhas conceituais, que culminaram no patenteamento industrial do IKB, Klein reteve três das qualidades mais arraigadas da pintura como uma operação estética institucionalizada - a mistificação do autor, o pictorialismo da tela tradicional e a passividade contemplativa do espectador - mesmo que cruamente projetasse essas qualidades na esfera econômica. Se Rodchenko abandonou a pintura pelo espaço e pelo que ele e seus companheiros construtivistas idealizavam como a esfera aplicada da tecnologia e da indústria, o trabalho de Klein ilustrou de forma inequívoca a facilidade com que os impulsos revolucionários poderiam ser absorvidos pelas forças de mercado. Ao proceder desta maneira, o trabalho de Klein também demonstrou que uma prática pós-pictórica do irromper das vanguardas históricas teria de se enraizar através da mercadoria. Não reconhecer sua influência estruturante seria simplesmente ignorar o problema.

Oiticica também confrontou as condições da mercadoria em uma prática pós-pictórica, embora em um contexto muito diferente, o do Brasil desenvolvimentista. As condições da produção econômica já eram centrais para os concretistas brasileiros, grupo contra o qual os neoconcretistas definiram sua identidade em seu manifesto inaugural de 1959. No Brasil, a arte concreta era parte de um amplo legado da abstração geométrica e da arte "construtiva”, que incluía manifestações pré-guerra, como o neoplasticismo e o construtivismo russo, como também a mobilização pós-guerra envolvendo Max Bill e Tomás Maldonado na escola de Ulm,
Irene V. Small

Pigment pur e o Corpo da côr: prática pós-pictórica e transmodernidade. 
em torno do termo "arte concreta" concebido por Theo van Doesburg em

22. Cf. CORDEIRO, Waldemar.

O objeto. AD: Arquitetura e

Decoração, São Paulo, n. 20, nov./dez. 1956; Idem. Arte industrial. AD: Arquitetura e

Decoração, São Paulo, n. 27, fev./mar. 1958; PIGNATARI,

Décio. Forma, função e projeto geral. AD: Arquitetura e Decoração, São Paulo, n. 24 , jul./ago. 1957.

23. ESCOLA SUPERIOR DO DESENHO INDUSTRIAL.

Documento interno. Rio de Janeiro: Secretaria de Educação e Cultura, Estado da Guanabara, c. 1960, p. 4. Cf.também SOUZA, Pedro. Esdi: biografia de uma idéia. Rio de Janeiro: Eduerj, 1996.

24. MORAIS, Frederico. Desenho industrial 68. Diário de Notícias, Porto Alegre, 15 ago. 1968

25. 0 governo brasileiro criou a Superintendência da Moeda e do Crédito (Sumoc) em 1945, a fim de exercer controle monetário nacional. Com a Instrução 70, de 9 de outubro de 1953, a Sumoc inaugurou um sistema hierárquico de múltiplas tarifas destinado

a proteger a florescente indústria nacional e estimular as exportações brasileiras no mercado internacional. Cf. FIGUEIREDO FILHO, João.

Políticas monetária, cambial e bancária no brasil sob a gestão do Conselho da Sumoc, de 1945 a 1955. 2005. $201 \mathrm{f}$ Dissertação (Mestrado em Economia) - Universidade Federal Fluminense, Niterói, 2005; VIANNA, Sérgio. A

política econômica no segundo governo Vargas (1951-1954). Rio de Janeiro: BNDES, 1987; KAFKA, Alexandre. The 1930. Pamilhando as abordagens de Bill e Maldonado, voltadas ao design, o concretismo brasileiro procurou alinhar a arte com a indústria moderna, através de procedimentos compartilhados como o racionalismo, a mecanização e o distanciamento da mão do $\operatorname{artista}^{22}$. Assumindo o papel do designer que fornece um protótipo ou esquema no lugar de uma obra de arte finalizada, o concretismo procurou elementarizar menos a pintura e mais a divisão do trabalho artístico. Com efeito, logo após Oiticica iniciar sua série Bólide em 1963, este paradigma foi formalizado no Rio de Janeiro na Escola Superior do Desenho Industrial, ou ESDI, uma escola de design industrial que procurou "atender às duas exigências de nossa sociedade industrial: o planejamento de produtos (Design Industrial) e o planejamento dos meios de Comunicação Visual (Design Gráfico)”23. Entretanto, como graduados da ESDI logo viriam a descobrir, a integração desigual do Brasil ao mercado global significava que o país continuava a desempenhar um papel estruturalmente subordinado no sistema de produção. O Brasil fornecia materiais brutos ou semi-processados para mercados externos, enquanto era forçado a comprar os produtos prontos de volta a um preço mais elevado. Por outro lado, quando produtos eram fabricados no país, era geralmente a mando de empresas estrangeiras, dando pouca oportunidade para processos integrados de design industrial. Como um crítico escreveu em 1968 acerca da incongruência essencial do modelo ESDI, "Nós [brasileiros] fabricamos o produto, não o desenho do produto" ${ }^{24}$.

Tais dependências estruturais eram legíveis mesmo dentro do microcontexto das tintas, de fabricação nacional e importadas. Em 1954, por exemplo, artistas encenaram um Salão Preto e Branco no $3^{\circ}$ Salão Nacional de Arte Moderna a fim de protestar contra os impostos exorbitantes sobre tintas importadas. Estes impostos haviam sido recentemente estabelecidos como parte das políticas desenvolvimentistas do governo, que priorizavam as importações destinadas à incipiente esfera industrial do Brasil. Em resposta a tal "greve da cor", o governo transferiu as tintas importadas da categoria "específica" de produtos de luxo para a categoria "geral" de matérias-primas, diminuindo assim o imposto $^{25}$. Agindo desta maneira, o governo em essência recalibrou o potencial industrial das belas-artes. Não mais concebida como uma atividade específica confinada a um domínio estético, a pintura era agora uma prática geral através da qual era possível facilitar o desenvolvimento da nação em geral. No contexto do Brasil desenvolvimentista, a mercadoria era, portanto, um objeto demasiado inconstante, flagelado pelas desigualdades do sistema econômico global moderno. A questão de uma 
prática pós-pictórica no Brasil, portanto, não é uma provocação restrita ao campo da história da arte, envolvendo, diferentemente, as próprias contradições da modernidade em geral.

Neste contexto, é significativo que o primeiro uso que Oiticica fez do pigmento bruto como material independente em B7 Bólide Vidro 1 coincidiu com seu primeiro uso de um objeto readymade ou pré-fabricado: os dois recipientes de vidro em cujo interior pigmentos haviam sido depositados. Ao recorrer a objetos readymade, Oiticica distanciava-se das noções tradicionais de autoria artística e aproximava-se de um conceito de apropriação que influenciaria muitos de seus trabalhos subsequentes. Em seu primeiro texto sobre os Bólides, de 19 de setembro de 1963, Oiticica descreveu um processo dual, mediante o qual as conotações existentes de objetos cotidianos do "mundo gasto de objetos, de nosso cotidiano" seriam abstraídas conforme o objeto fosse rearticulado através da "valorização espacial da côr" ${ }^{26}$. Nesta transformação do objeto naquilo que Oiticica, livremente baseado no filósofo Ernst Cassirer, chamou de uma "forma simbólica", o espectador redescobria o objeto no que diz respeito a suas qualidades primárias: "o sólido, o ôco, o redondo, seu peso [do objeto], sua transparência"27. Embora Oiticica tivesse notado que tais objetos inevitavelmente mantinham algumas de suas associações prévias, enfatizava que sua integração a um um sistema estético permitia "extrair novas possibilidades"28. "Extração", para Oiticica, era explicitamente simbólica e experiencial em vez de econômica.

Entretanto, o artista insistia prontamente que o uso de readymades não equivalia a uma "lirificação" ou elevação de objetos do cotidiano ao domínio da $\operatorname{arte}^{29}$. Ele já havia rejeitado o trabalho dos Nouveaux Réalistes precisamente porque caíam nessa armadilha, em $1962^{30}$. Em um segundo texto sobre os Bólides, distinguiu sua estratégia em face destas e de outras obras contemporâneas de assemblage. Ele observou, por exemplo, que os combines de Robert Rauschenberg operavam através de uma "incorporação a posteriori", um processo mediante o qual o objeto readymade, uma vez anexado a um apoio vertical ou horizontal, funcionava como um dos vários signos internos da obra de arte. Em tais obras, um objeto readymade é "transportado do 'mundo das coisas' para o plano das 'formas simbólicas' (...) de maneira direta e metafórica" ${ }^{31}$. Objetos arranjados em assemblage eram, portanto, "combinados" a outros elementos, como pinceladas e fotografias, por cima de um suporte retangular preexistente, sem levar em conta seu caráter estrutural (e não iconográfico). Em contraste, Oiticica procurou utilizar materiais pré-fabricados para desencadear identificações primárias
Irene V. Small

Pigment pur e o Corpo da côr: prática pós-pictórica e transmodernidade.

brazilian exchange auction system. Review of Economics and Statistics, Cambridge, MA, v. 38, n. 3, p. 308-322, ago. 1956. As categorias do sistema tarifário foram definidas de acordo com um espectro geral de processamento e necessidade: I - matériasprimas para a indústria farmacêutica e suprimentos agrícolas; II - matéria-prima; III - equipamentos industriais; IV - equipamento industrial de menor importância e bens de consumo; e V - todos os outros produtos. Em agosto de 1957, a Lei n 3.244 reduziu as categorias de cinco a duas: geral limportações de matérias-primas, bens de capital e bens de consumo essenciais) e específica (bens não considerados essenciais). A Instrução 97, de 29 de julho de 1954, moveu as "tintas preparadas para aquarela, desenho e pinturas finas, em tablets, tubos ou potes" para a segunda categoria, "a fim de estabelecer condições mais favoráveis á importação". BRASIL. Instrução no 97, de 29 de julho de 1954. Diário Oficial [da] República Federativa do Brasil, Superintendência da Moeda e do Crédito, Brasília, DF, agosto de 1954. Seção 1, p. 13380.

26. OITICICA, Hélio. Experiência dos bólides. 19 set. 1963. ITAÚ CULTURAL. Programa Hélio Oiticica. São Paulo, 2002, AHO/PHO 007/63, p. 1-2. Sobre os Bólides, cf. também LOEB, Angela. Os Bólides do programa ambiental de Hélio Oiticica. Ars, São Paulo, v. 9, n. 17, p. 49-77, 2010. Anna Dezeuze argumentou que a prática de Oiticica corresponde mais amplamente a uma estética de "bricolagem" em seu artigo 
"Assemblage, bricolage, and the practice of everyday life", Art Journal, Boston, v. 67, n. 1, p. 31-37, primavera 2008.

27. OITICICA, Hélio. Experiência dos bólides, 19 set. 1963. ITAÚ CULTURAL. Programa Hélio Oiticica. São Paulo, 2002, AHO/ $\mathrm{PHO} 007 / 63$, p. 1.

28. Ibidem, Loc. cit.

29. Idem. Bólides, 29 out. 1963. ITAÚ CULTURAL.

Programa Hélio Oiticica. São Paulo, 2002, AHO/PHO 1816/63, p. 1.

30. Cf. seu "A transição da côr do quadro para o espaço e o sentido de construtividade".

31. Ibidem. Para Oiticica, o momento em que

Rauschenberg mais se aproximou das preocupações estruturais foi com seu Pilgrim

(Peregrino) de 1960, que

Oiticica descreve, mas não

nomeia. Pilgrim é composto por um quadro pendurado atrás de uma cadeira. A tinta da tela se estende para a cadeira, mas como a cadeira está no chão em sua orientação normal, para Oiticica, ela não é incorporada dentro do espaço físico da pintura como um "sinal". Oiticica discutiu mais a fundo as implicações de uma abordagem "estrutural" do assemblage em relação às obras Popcreto de Waldemar Cordeiro, de 1964-1965, em

"Esquema geral da nova objetividade brasileira", em Nova objetividade brasileira (catálogo da exibição). Rio de Janeiro: MAM-RJ, 1967. 0 uso de Jasper Johns de uma bandeira americana como um dispositivo não composicional apropriado também deve ser considerado como uma solução "estrutural", que no entanto, Oiticica parece não ter considerado na época. evidente nos Bólides de vidro, em que recipientes readymade em vidro fornecem a estrutura material que dá forma a um material informe, flexível ou fluido, tal como pigmentos ou líquidos. A forma e a relação interna dos dois pigmentos de B7 Bólide Vidro 1 entropicamente se dissolveriam sem o suporte dos frascos readymade. Da mesma maneira, os pigmentos materializam a estrutura dos dois recipientes — tornando literais suas dimensões espaciais de um modo que não seria visível caso estes recipientes fossem deixados vazios. As categorias da obra e seus elementos readymade são interdependentes, cancelando-se a distinção hierárquica entre eles. Se por uma lado a objeção de Oiticica aos combines de Rauschenberg baseava-se no caráter percebido como arbitrário do objeto apropriado, porque incorporado para o interior de uma obra, por outro B7 Bólide Vidro 1 dependia da estrutura do objeto incorporado e a revelava naquilo que Oiticica chamou de "gênese" da obra. A transparência dos recipientes de vidro e sua função de contenção são, portanto, deliberadas, motivadas e generativas.

Confrontado com a articulação de uma série de distinções sutis mas críticas entre sua nova incorporação de objetos apropriados e práticas existentes relacionadas à herança Duchampiana do readymade, Oiticica cunhou um novo termo para seus Bólides: "transobjetos"32. Este conceito foi, sem dúvida, concebido em diálogo com a formulação prévia dos "não objetos" neoconcretos de Gullar, obras sem molduras ou pedestais que eram inseridas diretamente no espaço do espectador e dos objetos comuns ${ }^{33}$. Uma vez que não objetos não buscavam relacionar-se com essas coisas comuns, Gullar argumentou que eles não seriam readymades - por ele chamados de a "célebre blague" de Duchamp $^{34}$. Ao formular esta diferença, o crítico estava preocupado principalmente com a função redentora da experiência estética. Neste encontro, a obra de arte era apreendida como um "corpo transparente ao conhecimento fenomenológico" 35 . Objetos comuns, em contraste, eram familiares para os telespectadores, e, assim, caracterizados pela "obscuridade" perceptual. O readymade era um caso peculiar, pois tratava-se simplesmente de um objeto utilitário deslocado de sua função habitual. Em razão de seu caráter como arte não ser inerente a suas qualidades formais, "em breve aequela obscuridade característica da coisa volta a envolver a obra, requistando-a para o nível comum”36. Em outras palavras, como o readymade não tinha capacidade formal para manter sua diferença crítica em relação ao cotidiano, ele poderia retornar a seu estado anterior a partir do momento em que os efeitos 
autorais de seleção e nomeação retrocedessem. O que Duchamp celebrava como "não retiniano" era, para Gullar o "batido" da obra da $\operatorname{arte}^{37}$.

As obras de Oiticica, entre 1959 e 1962, enquadram-se com acuidade na caracterização de Gullar do não objeto. Mas em relação a seus Bólides - especialmente aqueles que empregam elementos readymade — o termo não mais se aplica. Gullar descreveu o não objeto como uma entidade que recusa se render ao "nível comum" e que "não pode ser classificada de acordo com seu uso e significado já que não se encaixa nem em uma categoria de utilização, nem em designação verbal"38. Com os Bólides, no entanto, Oiticica começou a incorporar elementos readymade que desempenhavam exatamente tais funções. Além disso, ele desenvolveu um sistema correspondente de designação em que termos como caixa, copo, bacia, lata, luz e cama descreviam a utilização desses elementos de que se apropriava. A categoria do "transobjeto" que Oiticica formulou procurou criar uma ponte entre o trabalho de arte e a coisa readymade. Transitava entre as categorias e as desmantelava em uma única entidade, assim como ocorria nos frascos de vidro e pigmentos de B7 Bólide Vidro 1. Assim, o "transobjeto" descreve um espaço de constituição estética em que a estrutura de um objeto preexistente assume papel generativo no trabalho de arte enquanto entidade fenomenológica, experiencial. Significativamente, foi a "valorização espacial da côr", como Oiticica denominou-a, que permitiu a este objeto readymade comportar-se não como uma entidade hermética ou fixa, mas como uma matriz aberta à ressignificação ${ }^{39}$.

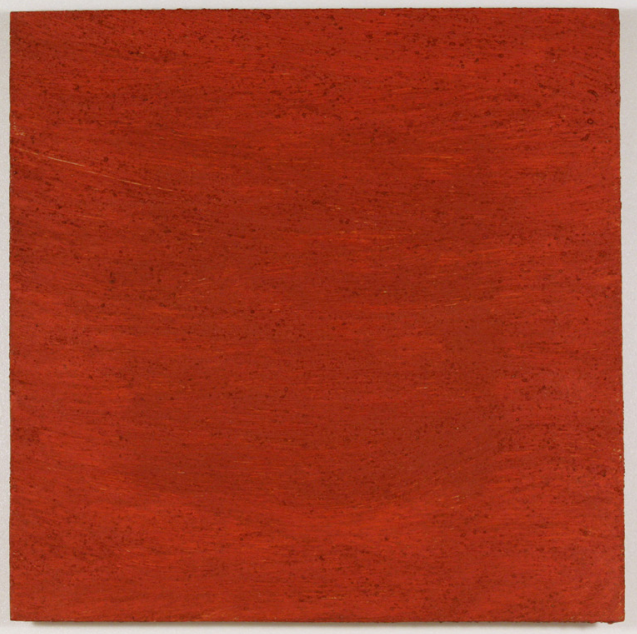

\section{Irene V. Small}

Pigment pur e o Corpo da côr: prática pós-pictórica e transmodernidade.

32. OITICICA, Hélio. Bólides. 29 out. 1963. ITAÚ CULTURAL. Programa Hélio Oiticica. São Paulo, 2002, AHO/PHO $1816 / 63$.

33. GULLAR, Ferreira. Teoria do não-objeto. Jornal do Brasil, 20 dez. 1959.

Suplemento Dominical, p. 1.

34. Ibidem.

35. Ibidem, ênfase no original.

36. Ibidem, ênfase no original. Gullar não parece considerar a apresentação de Duchamp de seus readymades, que simplesmente em sua orientação impediram o retorno "ao nível comum".

37. Ibidem.

38. Idem. Diálogo sobre o não-objeto. Jornal do Brasil, 26 mar. 1960. Suplemento Dominical, p. 4.

39. OITICICA, Hélio. Experiência dos bólides. 19 set. 1963. ITAÚ CULTURAL. Programa Hélio Oiticica. São Paulo, 2002, AHO/ $\mathrm{PHO} 007 / 63$, p. 1-2.

Fig. 8

Hélio Oiticica, Invenção 40 , 1959-96. Cortesia do Projeto Hélio Oiticica. (foto César Oiticica Filho) 
40. Idem. Registro em caderno, 3 mar. 1961. ITAÚ CULTURAL.

Programa Hélio Oiticica. São Paulo, 2002, AHO/PHO 0182/59, p. 43-44. Como ele escreveu, "A cor no vidro em seu estado pigmentar puro pertence ao mundo. Torna-se um elemento estético quando o artista a integra ao sistema de sua obra. (...) Um pintor de automóveis, por exemplo, remove a cor do elemento mundano e a integra a outro sistema, ainda que não se torne um elemento estético

(...) já que a cor, aqui, é sempre a cor 'de' uma coisa e 'para' algum objetivo. (...) Na obra de arte pura a cor é estética apenas em si mesma. É não utilitária por excelência".

41. Ibidem. Cf. também registro em caderno de 24 de agosto de 1961, em que ele escreve que "a cor só existe fisicamente para o artista como uma coisa química, mas como significado ultrapassa as limitações do 'físico', apesar de usar matéria para ser feita. Ao pintar uma superfície, o artista não pinta como se ele estivesse pintando uma 'coisa'.

No ato da pintura de fato, o artista sente que outra ordem, outra síntese, o orienta". ITAÚ CULTURAL. Programa Hélio Oiticica. São Paulo, 2002, AHO/ PHO 0187/61, p. 38.

Fig. 9 Hélio Oiticica, B12 Bólide Vidro

3 "Em memória de meu pai", 1964. Cortesia do Projeto Hélio Oiticica. (foto Alexandre Barattal terial independente, Oiticica tentou teorizar a distinção entre cor "estética" e "utilitária"40. Enquanto a cor funcional nunca poderia escapar do significado de sua aplicação - o que Oiticica descreveu como cor "de" ou "para" - a cor estética poderia atribuir significado a si própria quando extraída de um estado anterior e integrada em um sistema artístico. Nesta formulação inicial, o pigmento bruto "pertence ao mundo" e precedia ambas as categorias $^{41}$. Em 1962, no entanto, Oiticica radicalizou sua própria equação com uma série de pinturas de quadrados, cada uma composta por três ou quatro camadas independentes de tinta. Na última destas Invenções, Oiticica usou tijolo triturado para adicionar textura e cor. $\mathrm{O}$ material funcionava tanto como "côr estética", no que concerne a seu papel cromático determinante, $\mathrm{e}$ "côr de" tijolo em si. Ao retornar, essencialmente, um produto readymade a seu "estado ambiental" como óxido de ferro (por si só um pigmento natural), Oiticica usou cor nesta última Invenção para demonstrar a fungibilidade fundamental que atravessaria os estados naturais, estéticos e industriais.

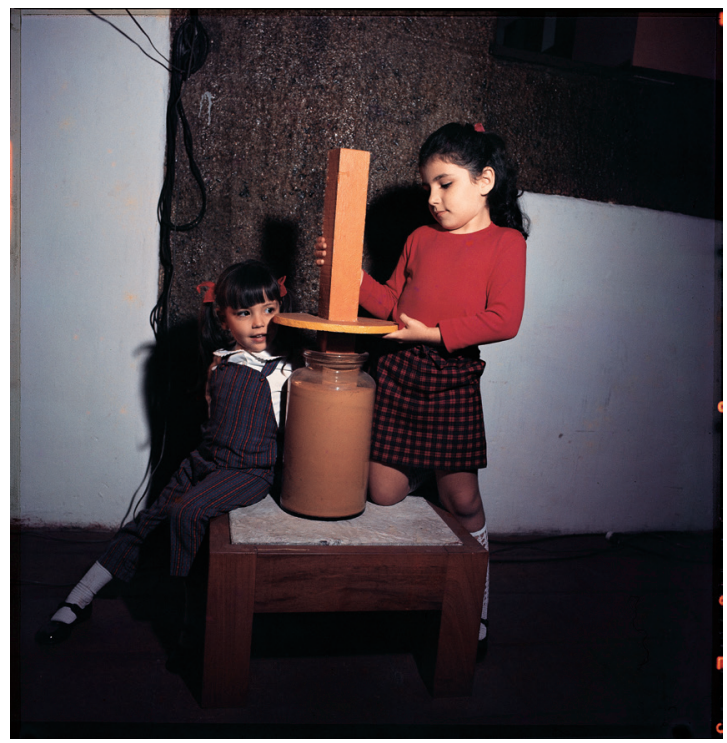

O uso subsequente que Oiticica fez do pigmento bruto como material escultural desmantelou mais profundamente tais hierarquias. Em B12 Bólide Vidro 3 "Em memória de meu pai" (1964), por exemplo, Oiticica misturou com aglutinante o pigmento ocre natural contido no pote de vidro da base da escultura, para fazer a tinta que reveste a tampa monumentalizada da obra. Os dois estados de cor da obra têm uma função demonstrativa: a cor "encontrada" do pigmento bruto demonstra 
a cor "feita" da tinta, gerando um circuito interno através do qual uma funciona como exemplificação da outra. Entretanto, esta reflexividade também se abre para fora, pois o pigmento ocre natural é, em seu nível mais fundamental, um elemento "do mundo". De fato, obras como B15 Bólide Vidro 4 "Terra" (1964), mostrando um rico pigmento de terra vermelho escavado do solo, e Bólide Vidro 14 "Estar" (1965-1966), uma acumulação de conchas brancas, enfatizam a cor estética como uma entidade encontrada, que radica nos próprios materiais brutos ${ }^{42}$. Se em 1961 Oiticica sentiu que a cor deveria ser incorporada ao sistema estético da pintura a fim de "significar-se a si mesma", a introdução de Bólides feitos com pigmentos brutos sugere que a autonomia da cor foi associada a fontes que preexistiam à tinta enquanto tal.

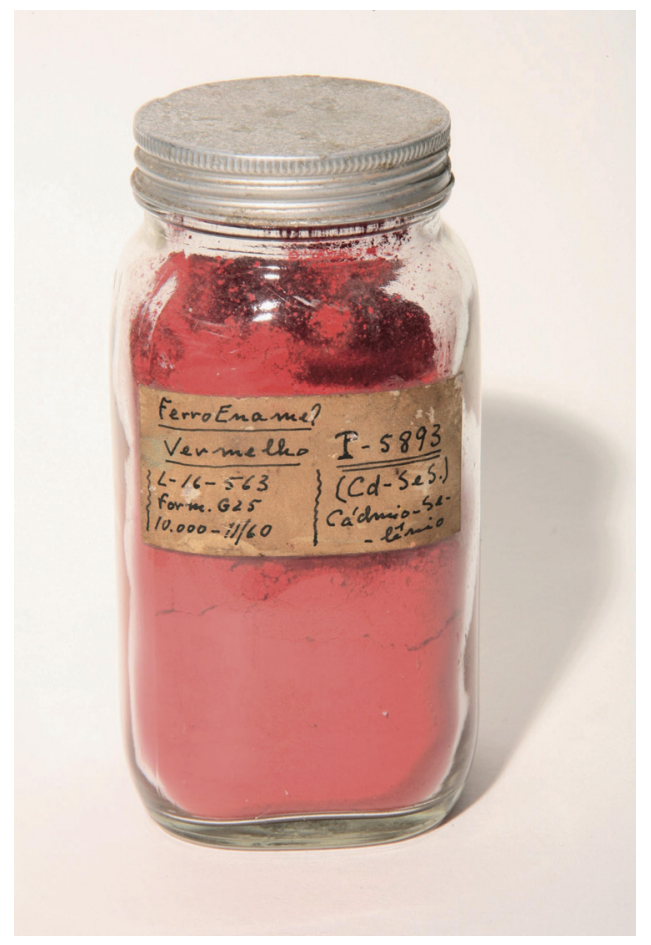

Entretanto, estas obras não mapeiam, simplesmente, a elementarização da pintura em direção à decomposição de materiais processados em estados mais rudimentares, ambientais. Tanto B7 Bólide Vidro 1 como B12 Bólide Vidro 3 "Em memória de meu pai” incorporam pigmentos que são readymade, ou seja, produtos de cor comerciais e industriais selecionados e comprados em uma loja. Na verdade, a tipologia do Bólide de vidro como um todo parece ter raízes em potes e frascos de pigmento de tinta que Oiticica e seu pai armazenavam

\section{Irene V. Small}

Pigment pur e o Corpo da côr: prática pós-pictórica e transmodernidade.

42. 0 irmão de Oiticica, César, recorda que Hélio encontrou a terra utilizada em B15 Bólide Vidro 4 "Terra" perto de sua casa e a coletou em sacos.

Fig. 10

Pigmento de esmalte de ferro do estúdio de José Oiticica Filho, [s/d]. Cortesia do Museu de Belas Artes, Houston e Projeto Hélio Oiticica. 
no estúdio da família, tais como o pigmento vermelho-cádmio que

ano 15

ก. 30

43. PHELAN, Wynne. To

bestow a sense of light: Hélio Oiticica's experimental process. In: RAMÍREZ, Mari (ed.). Op. cit., p. 100.

44. Marcel Duchamp, "Apropos of 'Readymades'”, discurso proferido no Museu de Arte Moderna, em outubro de 1961, posteriormente publicado em Art and Artists, London, v. 4, n. 1, p. 47, jul. 1966. Sobre a relação entre cor pictórica e o readymade, cf. DUVE, Thierry de. The readymade and the tube of paint. Artforum, Nova lorque, v. 24, n. 9, p. $110-121$, maio 1986, desenvolvido pelo autor no capítulo 3 de seu livro Kant after Duchamp. Cambridge, MA: MIT Press, 1996.

45. Cf. BRASIL. Instrução n० 87", de 20 de março de

1954. Diário Oficial [da]

República Federativa do

Brasil, Superintendência da Moeda e do Crédito, Brasília, DF, março de 1954. Seção 1, p. 4657. 0 Programa das Metras

do presidente Juscelino

Kubitschek de 1958 incluía 30

"metas"; a meta $n^{\circ} 26$ realçava as exportações de minerais e demandava um aumento de 2,5 a 8 milhões de toneladas, com preparações adicionais para outras 20 milhões de toneladas nos cinco anos seguintes.
Oiticica utilizou em várias de suas Invenções ${ }^{43}$. Nesta genealogia, os recipientes de vidro dos Bólides acenam para uma condição peculiar inerente à garrafa de pigmento: cor que é "readymade" antes de ter sido "encontrada" ou "feita" pelo artista. Desta maneira, eles identificam um estado intermediário ou "trans" da cor como uma forma da mercadoria, informada pelos fluxos de matéria e continuidade vital entre estados, pois diferentemente de um tubo de tinta, o pigmento readymade deve ser materialmente refeito para funcionar como tinta. Este misturar o pigmento em meio e aglutinante não altera sua substância cromática, pois cada grão é quimicamente insolúvel. Contudo, ele muda, sim, radicalmente os efeitos materiais do pigmento. Pigmento readymade não é, portanto, origem nem estado final da produção; é um espaço de transição que incorpora elementarização e transmutação ao mesmo tempo.

Em uma série de entrevistas e declarações do início da década de 1960, Marcel Duchamp comentou a provocação de sua dita última pintura, Tu m' (1918), observando que toda pintura era essencialmente readymade, um trabalho de assemblage ${ }^{44}$, uma vez que o tubo de tinta em si era um produto fabricado. Esta observação aparentemente situaria no século XIX a origem histórica de uma prática de pintura orientada à industrialização como também a regularização da cor por meio da fabricação de tubos de tinta. Entretanto, a história da cor processada indica uma trajetória mais complexa de comercialização, que vai desde a indústria medieval do lápis-lazúli à introdução no século XX do vermelho de cádmio. No Brasil, a transferência de tintas importadas da categoria de bens de luxo altamente tributados para a categoria de matérias-primas moderadamente tributadas, determinada em 1954, reposicionou a tinta, de mercadoria para o consumo a material para a produção. A nova lei colocou as belas-artes sob o signo da industrialização e concebeu o trabalho artístico em termos de transformação de matérias-primas em mercadorias. Pigmentos, no entanto, foram avaliados de forma diferente: aqueles destinados à indústria de tintas local foram importados a baixas tarifas, exceto os abundantes no Brasil, tais como os óxidos de ferro, que eram valorizados como commodities independentes para exportação e como matérias-primas destinadas à produção local ${ }^{45}$. O pigmento, ao contrário da tinta, jamais poderia escapar à identidade como mera matéria "bruta" e "mero" produto comercial. Seu status de "trans" no espectro industrial de produção de mercadoria coincidiu, assim, com sua posição intermediária em uma prática de pintura. 


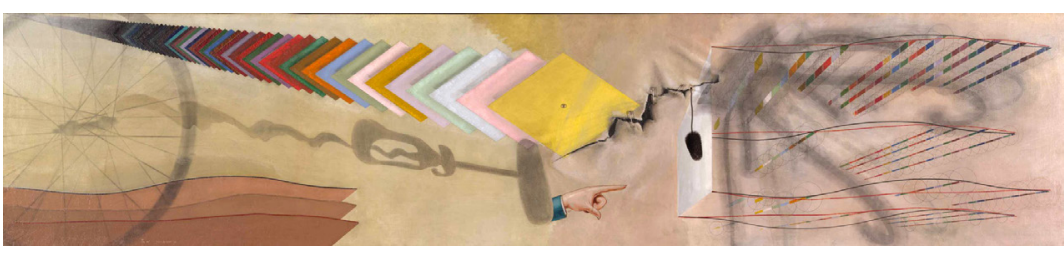

Os Bólides de Oiticica empregam uma ampla gama de materiais encontrados e readymade, desde revestimento plástico e luvas de borracha a carvão, cascalho e sacos de pigmento bruto comprados a granel. Através de seus materiais, Oiticica situou a cor muito além das esferas tradicionais da produção artística, ao mesmo tempo em que demonstrou como a cor de que se apropriava poderia "significar-se" enquanto "corpo de côr". Entretanto, através de seu emprego constante de pigmentos de óxido de ferro, ele repetidamente retornava às especificidades da prática pós-pictórica no Brasil. Em B15 Bólide Vidro 4 "Terra", o pigmento existe simplesmente como uma rica porção de terra, semelhante à argila, acumulada em um frasco de vidro. Em B34 Bólide Bacia 1 (1965-1966), ele consiste em uma porção de terra mais grossa, para se manipular com luvas. Em B12 Bólide Vidro 3, leva a forma mais processada do pigmento ocre, designado para uso comercial ou doméstico, e em B7 Bólide Vidro 1, aparece sob a forma de tijolos triturados, que resulta em um material quase idêntico à terra contida em $B 15 \mathrm{e}$ B34. Se em suas primeiras obras, como a Série Branca, Oiticica desmantelou a distinção entre tinta industrial e artesanal, seus Bólides aumentaram a aposta ao insistir que cores pigmentárias são concomitantemente brutas e readymade: brutas no sentido de que são extraídas na forma monista da matéria pura e indivisível; readymade, porque essas cores não são fisicamente criadas, mas encontradas ou selecionadas de um espectro fluído e reversível de uso industrial e ambiental. Simultaneamente pré-tinta e pós-tinta, os Bólides intervêm no âmbito da produção normativa da obra de arte tanto como mercadoria industrial como produto de trabalho intelectual e estético. Eles desorganizam a estabilidade de ambas as categorias ao revelar o fluxo material que funciona sob suas leis reguladoras. Quando em 1963 Oiticica declarou que era a "valorização espacial da côr" que permitiria a rearticulação do objeto readymade, foi porque sua cor bruta e readymade isolava uma inconsistência econômica latente, inerente à mercadoria, e a redirecionava na forma de uma alteração material explícita no interior da obra de arte.
272

Irene V. Small

Pigment pur e o Corpo da côr: prática pós-pictórica e transmodernidade.

Fig. 11

Marcel Duchamp, Tu m', 1918, óleo sobre tela, com escova de garrafa, alfinetes e parafuso, $69,8 \times 303 \mathrm{~cm}$, Succession Marcel Duchamp/ADAGP, Paris/Artists Rights Society (ARS), Nova lorque, 2017. 
Fig. 12

Hélio Oiticica, B34 Bólide Bacia 1, 1965-1966. Cortesia do Projeto Hélio Oiticica. (foto César Oiticica Filhol

46. OITICICA, Hélio. Bólides. 29 out. 1963. ITAÚ CULTURAL.

Programa Hélio Oiticica. São Paulo, 2002, AHO/PHO 1816/63, p. 1.

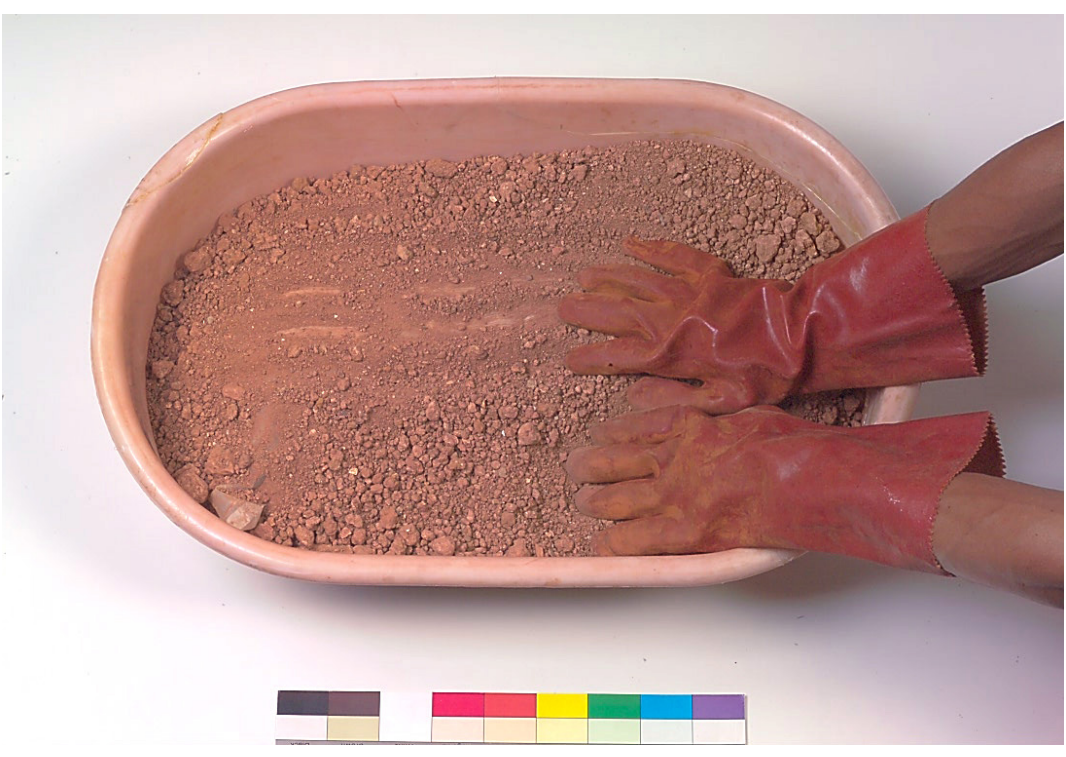

Foi esta abordagem — tratar objetos aparentemente fixos ou inanimados como entidades mutáveis, receptivas à transformação, incorporando-a de fato - que permitiu a Oiticica mobilizar a mercadoria como matéria in potentia e, ainda, articulá-la em termos de fluxo, ao invés de justaposição. Em seu texto de outubro de 1963 sobre os Bólides, Oiticica descreveu "a cuba de vidro que contém a cor" como um "objeto pré-moldado, visto já estar pronto de antemão"46. O readymade, para Oiticica, seria uma entidade capaz de ser ativada, ou refeita, através do vitalismo de sua matéria colorida. Em seus primeiros trabalhos de pintura, este vitalismo estava intimamente ligado a um diálogo colaborativo entre o agente e o material - diálogo que procurou resistir à acomodação do concretismo à lógica industrial da mercadoria. Esta posição utilizava materiais pós-industriais, tais como a tinta comercial, para recuperar uma relação basicamente pré-industrial com o trabalho artístico. Entretanto, em meio ao advento de uma verdadeira eliminação da mão do artista, resultado do uso do readymade como também da crescente dimensão participativa dos Bólides, agora era o espectador que assumia o papel de pesquisador e experimentador. Mas em vez de se aproximar da criação física do artista, este espectador "desenvolve" e "revela" o "corpo de côr" com o readymade. Adotando o readymade simultaneamente como recipiente (frasco) e conteúdo (pigmento) da obra nos Bólides, Oiticica recalibrou um mapeamento metafórico crucial entre a mercadoria e a obra de arte. Ao invés de apelar para sua mistificação, como na retenção que Klein operava, da passividade essencial do sujeito observador, ele penetrou a própria materialidade da 
mercadoria a fim de reconfigurar o papel do observador. Fluxo e fungibilidade - qualidades que tipificam a mercadoria submetida à lógica da troca econômica - são reformulados como operações materiais, de fato basicamente subterrâneas, que podem ser aproveitadas e redirecionadas pelo participante em consonância com a obra ${ }^{47}$.

Fazer cor com o readymade, portanto, não é fazer cor em um sentido artesanal. É construir um "corpo de côr" a partir da mutabilidade da mercadoria e, ao fazê-lo, canalizar seu status "trans" em direção à emergência conceitual e perceptual da obra de arte. Por meio deste processo, o caráter temporal do fazer muda. Já não mais limitado a um ato específico iniciado pelo artista, ele é iterativo e móvel, tomando como seu locus o corpo do espectador, em vez de qualquer outra instância. Em B34 Bólide Bacia 1, que convida o espectador a inspecionar sua matéria pigmentar à mão, ou B11 Bólide Caixa 9, em que uma bandeja de pigmento de açafrão brilhante pode ser exposta a diferentes graus de luz, o espectador libera um "corpo de côr" ao metabolizar a mercadoria, convertendo sua fisicalidade em energia cromática que depende da visão e do toque.

Precisamente por este motivo, é significativo que Oiticica tenha procurado maximizar a variabilidade da cor mesmo no nível granular do pigmento. Como Wynne Phelan observou nos testes de conservação de sua obra, Oiticica utilizava com frequência pigmentos com altos níveis de sílica moída, que são particularmente sensíveis à luz ${ }^{48}$. Tais materiais eram muito usados como coadjuvantes em pigmentos baratos e indicam precisamente o tipo de misturas inferiores a que artistas brasileiros objetavam, no que concernia às tintas domésticas. A variação cromática inerente a tais impurezas era pouco atrativa aos pintores que buscavam estabilidade material e permanência, bem como àqueles que, como Klein, queriam produzir uma sensação de cor reconhecível e consistente em toda uma gama de aplicações. Mas, para Oiticica, que estava interessado na contingência da percepção de cor, esta qualidade proteica era altamente desejável, pois ressaltava como o "corpo de côr" era literalmente construído no processo temporal do ver. Com efeito, a capacidade de tais impurezas de ampliar a interação da matéria e da luz é talvez a evidência mais concreta de como a cor nos Bólides é "feita" no olho do espectador. A cor, afinal, nada mais é do que a percepção do espectador da interação da matéria e da luz. Ao intensificar, ao invés de minimizar, a variabilidade destes elementos, os Bólides tornam o processo do ver reflexivo e explícito. O pigmento não é uma forma de evidência, como no conceito de Klein, mas um material construtivo primordial, aguardando a intervenção do espectador.
Irene V. Small

Pigment pur e o Corpo da côr: prática pós-pictórica e transmodernidade.

47. Oiticica elaboraria um princípio do "subterrâneo" em um texto de 21 de setembro de 1969, em que reflete sobre um conjunto mais amplo de condições que flexionam a produção artística nas "sub"-zonas como a América Latina. Como ele escreveu, o “subterrâneo" é não "um novo tipo de vanguarda (...) é uma condição, assim como estar aqui não pode ser o mesmo que estar ali; as posições são radicalmente diferentes". “Subterrânia”, em ITAÚ CULTURAL. Programa Hélio Oiticica. São Paulo, 2002, AHO/PHO 0382/69.

48. PHELAN, Wynne. To bestow a sense of light: Hélio Oiticica's experimental process. In: RAMÍREZ, Mari (ed.). Op. cit., p. 99. 


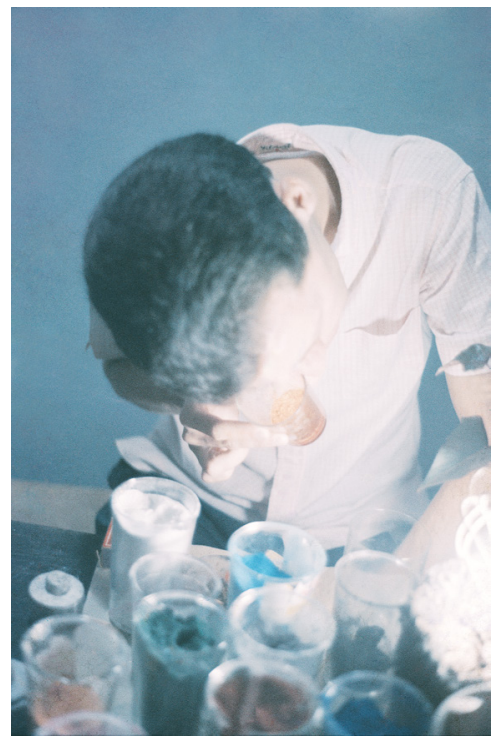

49. GUINLE FILHO, Jorge. A última entrevista de Hélio Oiticica. Interview, Nova lorque, p. 82, abr. 1980.
Com os Bólides, a obra de arte não é o resíduo de um evento artístico passado; é um ambiente em que tal evento poderia acontecer. Enquanto "estruturas para inspeção", como Oiticica mais tarde os descreveu, os Bólides pedem para ser tocados: as gavetas de pigmento reclamam ser abertas, seus paneis devem ser girados para frente e para trás; os compartimentos internos convidam a ser descobertos, a matéria, manipulada e as fendas, reveladas ${ }^{49}$. Na verdade, é apenas por meio do toque do espectador - modulando a luz sobre os conteúdos de uma escultura, mudando sua orientação - que os Bólides são capazes de liberar totalmente seu "corpo de côr". As obras, assim, criam não apenas uma arena para a exploração cromática, mas também um modelo físico do modo como a cor em si é formada. A afirmação muitas vezes repetida de Oiticica de que os Bólides procuram dar à cor um corpo refere-se não apenas à maneira como as obras materializam a cor, mas também ao modo como modelam seu comportamento enquanto fenômeno orgânico constituído através do espectador e por ele, no curso do tempo. Com os Bólides, o ato perceptivo do espectador é exteriorizado de forma física e redobrado como o processo participativo mediante o qual esta forma é revelada. Se a incorporação, por Oiticica, de elementos pré-fabricados reduziu ou eliminou a mão do artista, o toque retorna como parte crítica da contribuição do espectador. Este, talvez, é o aspecto mais radical dos Bólides. Em sua prática inicial, o artista fazia cor de modo que fosse encontrada pelo espectador; com os Bólides, Oiticica encontra cores readymade e então convida o espectador a construir e a liberar seu corpo através da obra. 


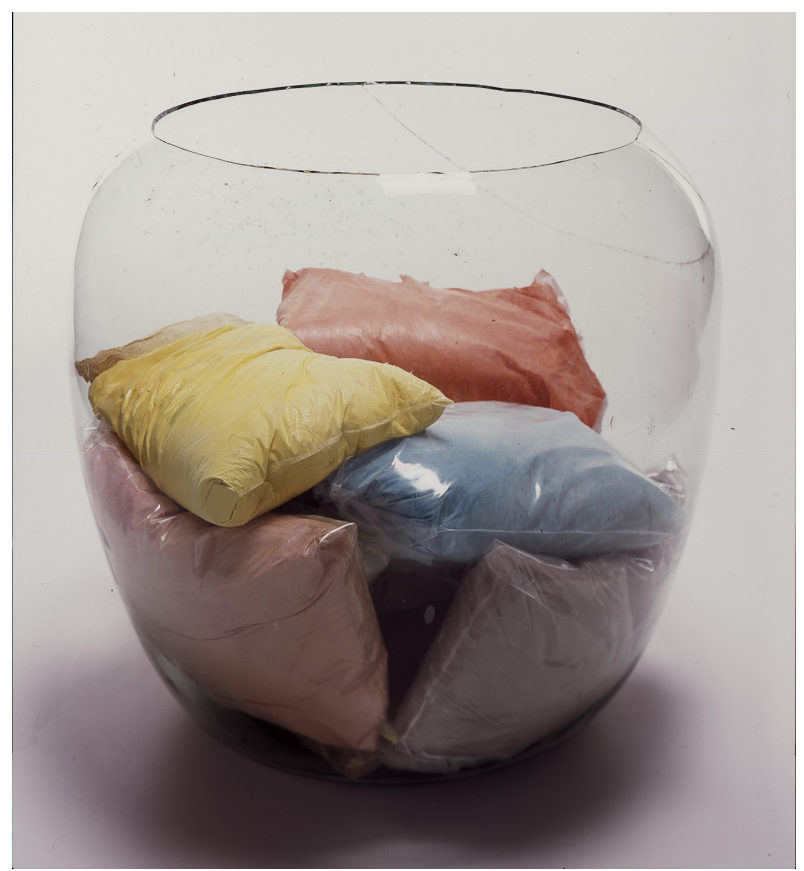

Os Bólides reconfiguraram as coordenadas contemporâneas da pintura no Brasil, especificamente, o desejo de alinhar a pintura com a modernização, a aceleração de desenvolvimento nacional e a estimulação da esfera industrial. Oiticica absorveu algo desses discursos, mas ao invés de tratar da mercadoria como o ápice do processo industrial, ele escavou sua materialidade para acessar um estado de fluxo reversível e fluido. Esse status "trans" é indicativo de inconsistências da mercadoria em um mercado mundial desigual. Na medida em que este sistema de mercado é, em si, um produto da modernidade, tal incidência da prática pós-pictórica demonstra que as intervenções estéticas são necessariamente transmodernas em sua articulação. Segue-se que a modernidade não é nem plural, nem inequivocamente singular, mas um campo de tensões desestabilizadoras, interativas. $\mathrm{O}$ impulso subterrâneo dos Bólides de Oiticica, em suma, assombra o projeto modernista em geral.

Irene V. Small é professora assistente no Departamento de Arte e Arqueologia e Preceptora Presidencial de Harold Willis Dodds na Princeton University, onde ela ensina arte e crítica moderna e contemporânea dentro de um contexto global. Ela é afiliada aos Programas de Estudos Latino-Americanos, Mídia e Modernidade e ao Departamento de Espanhol e Português. Ela é a autora da obra Hélio Oiticica: folding the frame [University of Chicago Press, 2016].
Irene V. Small

Pigment pur e o Corpo da côr: prática pós-pictórica e transmodernidade.

Fig. 14

Hélio Oiticica, B32 Bólide Vidro 15, 1965-1956. Cortesia do Projeto Hélio Oiticica. (foto César Oiticica Filho]

Artigo recebido em 20 de junho de 2017 e aceito em 3 de julho de 2017. 